\title{
Coherency strain engineered decomposition of unstable multilayer alloys for improved thermal stability
}

Rikard Forsén, Naureen Ghafoor and Magnus Odén

\section{Linköping University Post Print}

\section{Tweet}

N.B.: When citing this work, cite the original article.

Original Publication:

Rikard Forsén, Naureen Ghafoor and Magnus Odén, Coherency strain engineered decomposition of unstable multilayer alloys for improved thermal stability, 2013, Journal of Applied Physics, (114), 24, 244303.

http://dx.doi.org/10.1063/1.4851836

Copyright: American Institute of Physics (AIP) http://www.aip.org/

Postprint available at: Linköping University Electronic Press http://urn.kb.se/resolve?urn=urn:nbn:se:liu:diva-103072 


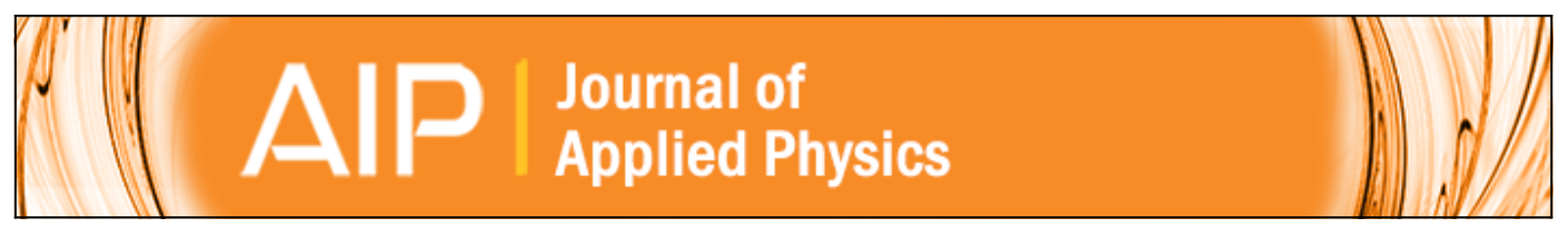

Coherency strain engineered decomposition of unstable multilayer alloys for improved thermal stability

R. Forsén, N. Ghafoor, and M. Odén

Citation: Journal of Applied Physics 114, 244303 (2013); doi: 10.1063/1.4851836

View online: http://dx.doi.org/10.1063/1.4851836

View Table of Contents: http://scitation.aip.org/content/aip/journal/jap/114/24?ver=pdfcov

Published by the AIP Publishing

AAP Re-register for Table of Content Alerts 


\title{
Coherency strain engineered decomposition of unstable multilayer alloys for improved thermal stability
}

\author{
R. Forsén, N. Ghafoor, and M. Odén \\ Nanostructured Materials, Department of Physics, Chemistry, and Biology (IFM), Linköping University, \\ 58183 Linköping, Sweden
}

(Received 14 November 2013; accepted 5 December 2013; published online 23 December 2013)

\begin{abstract}
A concept to improve hardness and thermal stability of unstable multilayer alloys is presented based on control of the coherency strain such that the driving force for decomposition is favorably altered. Cathodic arc evaporated cubic TiCrAlN/Ti ${ }_{1-x} \mathrm{Cr}_{\mathrm{x}} \mathrm{N}$ multilayer coatings are used as demonstrators. Upon annealing, the coatings undergo spinodal decomposition into nanometer-sized coherent Ti- and Al-rich cubic domains which is affected by the coherency strain. In addition, the growth of the domains is restricted by the surrounding TiCrN layer compared to a non-layered TiCrAlN coating which together results in an improved thermal stability of the cubic structure. A significant hardness increase is seen during decomposition for the case with high coherency strain while a low coherency strain results in a hardness decrease for high annealing temperatures. The metal diffusion paths during the domain coarsening are affected by strain which in turn is controlled by the $\mathrm{Cr}$-content (x) in the $\mathrm{Ti}_{1-\mathrm{x}} \mathrm{Cr}_{\mathrm{x}} \mathrm{N}$ layers. For $\mathrm{x}=0$ the diffusion occurs both parallel and perpendicular to the growth direction but for $\mathrm{x}>=0.9$ the diffusion occurs predominantly parallel to the growth direction. Altogether this study shows a structural tool to alter and fine-tune high temperature properties of multicomponent materials. (C) 2013 AIP Publishing LLC. [http://dx.doi.org/10.1063/1.4851836]
\end{abstract}

\section{INTRODUCTION}

The hardness of coatings is vital to protect cutting tools in high speed and dry cutting applications during which the temperature may exceed $1000^{\circ} \mathrm{C} .{ }^{1,2}$ Cubic $(c)$-TiAlN is a commonly used material system for abrasive wear protection. TiAlN coatings exhibit a hardness increase at $\sim 900^{\circ} \mathrm{C}$ due to spinodal decomposition into coherent nanometersized $c$-AlN and $c$-TiN domains. ${ }^{3-5}$ At higher temperatures the domains grow and $c$-AIN transforms into hexagonal $(h)$ AIN resulting in a significant hardness decrease. ${ }^{4,6}$ Different concepts have been applied to suppress this unfavorable transformation and to maintain a coherent cubic structure with a high hardness. One successful approach is through a multilayer structure of $c$-TiAlN/c-TiN where the surrounding $c$-TiN layers affect the decomposition by suppressing the growth and formation of incoherent $h$-AlN domains. ${ }^{7-9}$ Another approach is alloying TiAlN with $\mathrm{Cr}$ which has shown promising results by introducing intermediate decomposition steps yielding improved hardness, oxidation, and wear resistance. ${ }^{10-17} \mathrm{Cr}$-alloyed TiAlN coatings exhibit spinodal decomposition at $900-1000{ }^{\circ} \mathrm{C}$ into coherent nanometer-sized $c-\mathrm{TiCr}(\mathrm{Al}) \mathrm{N}$ and $c$ - $(\mathrm{TiCr}) \mathrm{AlN}$ domains during which the hardness increases (where elements within parentheses indicate a low content). The lattice parameter of $c$-CrN is in-between $c$-TiN and $c$-AlN (Ref. 18) which reduces the coherency strain and results in a less pronounced hardness increase for $\mathrm{Ti}_{0.31} \mathrm{Cr}_{0.07} \mathrm{Al}_{0.62} \mathrm{~N}$ compared to $c-\mathrm{Ti}_{0.33} \mathrm{Al}_{0.67} \mathrm{~N}$. ${ }^{19}$ However, the positive effect of the reduced coherency strain is a lower driving force for relaxation of the strained domain boundaries at higher temperatures. As a result, the $\mathrm{Cr}$-alloyed $c$-TiAlN coatings remain in a strained state with a significantly higher hardness between 1000 and $1100{ }^{\circ} \mathrm{C}$ compared to $c$-TiAlN. The transformation of $c$-AlN to $h$-AlN occurs at higher temperatures resulting in a hardness decrease when the strain relaxes forming incoherent boundaries. ${ }^{10,19,20}$ Here, we propose a concept of coherency strain engineering to affect the high temperature behavior of hard coatings which can be used to further improve the thermal stability of TiCrAlN coatings.

$\mathrm{Ti}_{0.31} \mathrm{Cr}_{0.07} \mathrm{Al}_{0.62} \mathrm{~N}$ is a composition that we have studied previously ${ }^{10,19}$ and here it serves as the motif layer embedded in different $c-\mathrm{Ti}_{1-\mathrm{x}} \mathrm{Cr}_{\mathrm{X}} \mathrm{N}$ layers. The $c-\mathrm{Ti}_{1-\mathrm{x}} \mathrm{Cr}_{\mathrm{X}} \mathrm{N}$ layers are chosen since they are predicted to be stable at elevated temperatures. ${ }^{10}$ Variations in $\mathrm{x}$ (Cr-content) will allow for tuning of the lattice parameter mismatch between the layers, or in other words, tuning of the coherency strain which affects the hardness. ${ }^{8,21-23}$ The multilayer periodicity and, in particular, the stability of $c$-AIN are also important parameters affecting the hardness. $8,21,23-27$ Based on this knowledge, the periodicity was kept at $\sim 8 \mathrm{~nm}$ with the aim to retain a cubic structure, but further optimization of the layer periodicity may result in improved stabilization and higher hardness.

Hence, the phase and microstructure evolution and hardness of coatings annealed up to $1200^{\circ} \mathrm{C}$ are presented. To perform the study we have used high-resolution transmission electron microscopy (HRTEM), analytical scanning transmission electron microscopy (STEM), X-ray diffractometry (XRD) and nanoindentation.

\section{EXPERIMENTAL DETAILS}

The coatings presented in this work were deposited with an industrial Sulzer/Metaplas MZR-323 reactive cathodic arc evaporation system using compound cathodes in a pure $\mathrm{N}_{2}$ atmosphere on polished WC-Co (10 at. \% Co) substrates mounted on a rotating drum fixture. For more details regarding the deposition system, see Ref. 8. During the depositions, 
all deposition parameters were fixed except that different combinations of cathodes were used. To deposit the multilayered structures, three circular cathodes, $63 \mathrm{~mm}$ in diameter, with a composition of $\mathrm{Ti}_{29} \mathrm{Cr}_{5} \mathrm{Al}_{66}$ were vertically mounted in one line and equidistantly separated by $15 \mathrm{~cm}$ on one of the cathode flanges of the deposition chamber. On the opposite side, two cathodes of $\mathrm{Ti}$ and one cathode of $\mathrm{Cr}$ were also vertically mounted in one line in the following order: $\mathrm{Ti}, \mathrm{Cr}$, and $\mathrm{Ti}$, see Figure 1. Using this setup a varying deposition flux of different species obtained over the height of the drum fixture providing a compositional gradient, in this case $\mathrm{Ti}_{1-x} \mathrm{Cr}_{\mathrm{x}} \mathrm{N}$. The substrates were cleaned in ultrasonic baths of an alkali solution and alcohol prior to being sputter cleaned with $\mathrm{Ar}$ ions before the deposition. The system was pumped to a pressure of less than $2.0 \times 10^{-3} \mathrm{~Pa}$ prior to the deposition. During deposition the cathode current was $60 \mathrm{~A}$ and the $\mathrm{N}_{2}$ pressure 4.5 Pa. The deposition time was $2 \mathrm{~h}$ using a drum rotation of $7 \mathrm{rpm}$ (when growing multilayers), a substrate temperature of approximately $500^{\circ} \mathrm{C}$ and a fixed substrate bias of $-40 \mathrm{~V}$. All samples also contain a $\sim 100 \mathrm{~nm}$ thick TiN buffer layer deposited using the same parameters. The buffer layer acts as a barrier preventing Co from diffusing into the coating.

The relative concentrations of the metallic elements in the coatings were determined using energy-dispersive $\mathrm{x}$-ray spectroscopy (EDX). The accuracy of the EDX measurements was estimated to be \pm 4 at. $\%$ by comparison to our results obtained using elastic recoil detection analysis (ERDA) data recorded from similar samples. ${ }^{10,11,19}$ EDX analysis was performed with a Leo 1550 Gemini scanning electron microscope operated at $20 \mathrm{kV}$ and a working distance of $10 \mathrm{~mm}$. The obtained compositions and the layer thicknesses are presented in Table I.

Post deposition isothermal anneals were performed at $\mathrm{T}_{\max }=800,900,1000,1100$, and $1200^{\circ} \mathrm{C}$ for $2 \mathrm{~h}$ in an argon atmosphere at atmospheric pressure using a Sintervac furnace from GCA Vacuum Industries. The heating procedure is well described in Refs. 11 and 19.

$\mathrm{X}$-ray $\theta-2 \theta$ diffractograms with a $2 \theta$ range from $20^{\circ}$ to $80^{\circ}$ were recorded with a Panalytical X'Pert PRO MRD $\mathrm{X}$-ray diffractometer using $\mathrm{Cu}_{\alpha}$ radiation.

Transmission electron microscopy (TEM) and X-ray energy dispersive spectroscopy were carried out with a FEI Tecnai $\mathrm{G}^{2}$ TF 20 UT microscope. The hardness of the coatings

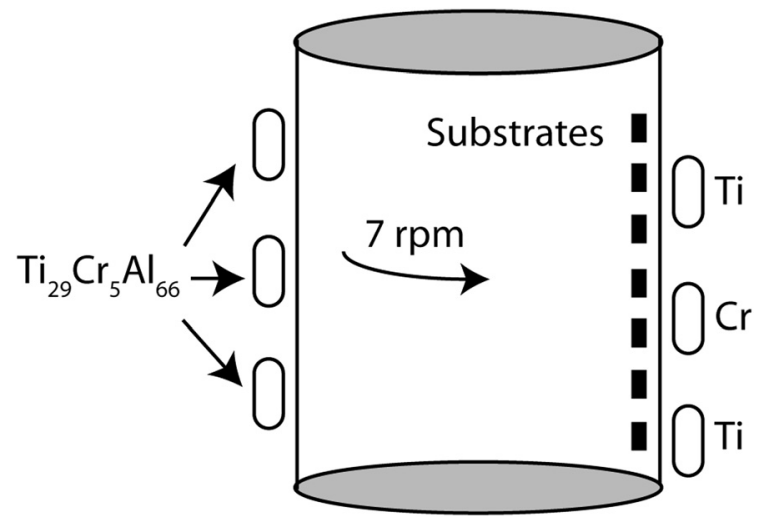

FIG. 1. Sketch of deposition system, sample fixture, and the positions of the cathodes.
TABLE I. The composition, layer thicknesses, period, and an estimate of the lattice parameter mismatch of each sample in the as deposited state.

\begin{tabular}{|c|c|c|c|c|}
\hline \multirow[b]{3}{*}{ Sample } & \multicolumn{2}{|c|}{$\left(\mathrm{Ti}_{0.31} \mathrm{Cr}_{0.07} \mathrm{Al}_{0.62}\right)_{1} \mathrm{~N}_{1} /\left(\mathrm{Ti}_{1-\mathrm{x}} \mathrm{Cr}_{\mathrm{x}}\right)_{1} \mathrm{~N}_{1}$} & \multirow[b]{3}{*}{$\begin{array}{l}\mathrm{a} 2 \\
{[\AA]}\end{array}$} & \multirow{3}{*}{$\begin{array}{c}\sim \frac{\mathrm{a} 2-\mathrm{a} 1}{\mathrm{a} 2} \\
\text { Mismatch } \\
{[\%]}\end{array}$} \\
\hline & $\mathrm{a} 1=4.14 \AA$ & $\mathrm{a} 2$ & & \\
\hline & Composition & $\begin{array}{l}\text { Period: } \pm 1 \\
\text { [nm] }\end{array}$ & & \\
\hline $1 \mathrm{TiN}$ & $x=0$ & $8(4 / 4)$ & 4.24 & 2.4 \\
\hline $2 \mathrm{Ti}_{0.95} \mathrm{Cr}_{0.05} \mathrm{~N}$ & $\mathrm{x}<0.05$ & $9(2 / 7)$ & 4.235 & 2.2 \\
\hline $3 \mathrm{Ti}_{0.8} \mathrm{Cr}_{0.2} \mathrm{~N}$ & $\mathrm{x}=0.2 \pm 0.04$ & $9(4 / 5)$ & 4.22 & 1.9 \\
\hline $4 \mathrm{Ti}_{0.4} \mathrm{Cr}_{0.6} \mathrm{~N}$ & $x=0.6 \pm 0.04$ & $8(3 / 5)$ & 4.18 & 1.0 \\
\hline $5 \mathrm{Ti}_{0.2} \mathrm{Cr}_{0.8} \mathrm{~N}$ & $\mathrm{x}=0.8 \pm 0.04$ & $6(3 / 3)$ & 4.16 & 0.5 \\
\hline $6 \mathrm{Ti}_{0.1} \mathrm{Cr}_{0.9} \mathrm{~N}$ & $\mathrm{x}=0.9 \pm 0.04$ & $6(2 / 4)$ & 4.15 & 0.2 \\
\hline $7 \mathrm{Ti}_{0.1} \mathrm{Cr}_{0.9} \mathrm{~N}$ & $x=0.9 \pm 0.04$ & $7(3 / 4)$ & 4.15 & 0.2 \\
\hline
\end{tabular}

was measured using an UMIS nanoindenter equipped with a Berkovich diamond tip. Indentation was performed on mechanically ground and polished tapered cross sections of the coatings using a tapering angle of $\sim 10^{\circ}$. The average hardness ${ }^{28}$ \pm 1 standard deviation was determined from approximately 30 indents on each sample using a maximum load of $40-50 \mathrm{mN}$.

\section{RESULTS AND DISCUSSION}

Table I contains information about the compositions, thicknesses, and estimates of the lattice parameter mismatches between the layers in each sample (based on a linear combination of the lattice parameters, $c$-AlN $4.1 \AA$ (theoreti$\left.\mathrm{cal}^{29}\right), c$-CrN $4.14 \AA$ and $c$-TiN $4.24 \AA$ ). The composition of the Al-containing layer is the same for all samples, i.e., $\mathrm{Ti}_{0.31} \mathrm{Cr}_{0.07} \mathrm{Al}_{0.62} \mathrm{~N}$. The $\mathrm{Ti}_{1-\mathrm{x}} \mathrm{Cr}_{\mathrm{x}} \mathrm{N}$ layer composition ranges from pure $\operatorname{TiN}(\mathrm{x}=0)$ to $\mathrm{Ti}_{0.1} \mathrm{Cr}_{0.9} \mathrm{~N}(\mathrm{x}=0.9)$. Since the samples were mounted in a vertical row their shortest distance to the cathodes differed, which resulted in slightly different layer thicknesses and thus different multilayer periods $\left(a_{1}\right.$ and $\mathrm{a}_{2}$ ) between the samples. We note that the metallic composition of the $\mathrm{Ti}_{0.31} \mathrm{Cr}_{0.07} \mathrm{Al}_{0.62} \mathrm{~N}$ layer deviates slightly from the cathode composition (as stated by the manufacturer), which is likely an effect of resputtering of the lighter $\mathrm{Al}^{30}$ The result section is focused on the two extreme compositions representing the samples with the highest and the lowest lattice mismatch, which are $\operatorname{TiN}(\mathrm{x}=0)$ and $\mathrm{Ti}_{0.1} \mathrm{Cr}_{0.9} \mathrm{~N}(\mathrm{x}=0.9)$.

Fig. 2(a) shows a lattice resolved TEM micrograph of the $\mathrm{Ti}_{0.31} \mathrm{Cr}_{0.07} \mathrm{Al}_{0.62} \mathrm{~N} / \mathrm{TiN}$ as deposited coating. It reveals a cubic crystal lattice $(\langle 011\rangle$ zone axis) coherent across the layers generating a mismatch strain which was observed for all samples. Fig. 2(b) shows a Z-contrast micrograph depicting layers in the growth direction with a period of $8(4+4) \mathrm{nm}$.

\section{A. Structure and phase evolution upon annealing}

Fig. 3(a) shows EDX line scan results obtained along the growth direction perpendicular to the layers for $\mathrm{Ti}_{0.31} \mathrm{Cr}_{0.07} \mathrm{Al}_{0.62} \mathrm{~N} / \mathrm{TiN}$ in its as deposited state and after annealing at 900,1100 , and $1200^{\circ} \mathrm{C}$. In the as deposited state there is a layer intermixing with approximately $2 \mathrm{~nm}$ wide interfaces (same for all samples) which probably is an overestimate because of projection effects in the TEM. The Y-axis (counts) has been normalized for each signal, respectively, in 


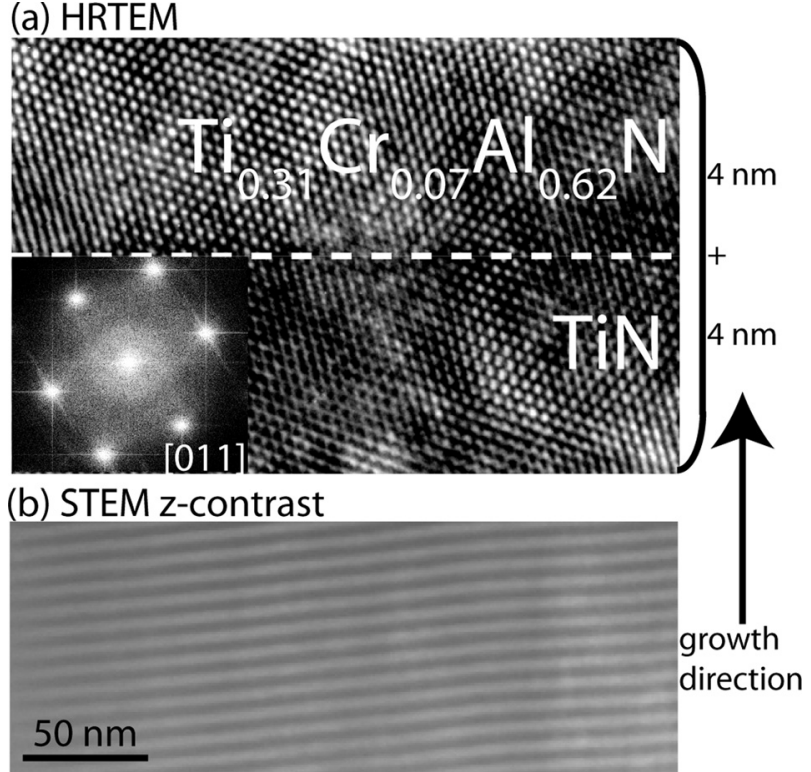

FIG. 2. (a) High resolution micrograph with its FFT showing a cubic coherent lattice $(\langle 011\rangle$ zone axis) in the as deposited state of $\mathrm{Ti}_{0.31} \mathrm{Cr}_{0.07} \mathrm{Al}_{0.62} \mathrm{~N} / \mathrm{TiN}$. (b) A Z-contrast micrograph of the multilayer structure in the growth direction.

order to emphasis the metal correlation (normalization was performed by setting the highest count number for each element to 1 and the lowest to 0 ). The Cr-content is low which results in a Cr-signal with poor statistics. Despite the inaccuracy of the Cr-signal, it can be seen that at $900^{\circ} \mathrm{C}, \mathrm{Ti}$ and $\mathrm{Al}$ have segregated and that $\mathrm{Cr}$ has relocated to the TiN layer. At 1100 and $1200^{\circ} \mathrm{C}$, the segregation is becoming more pronounced in terms of higher compositional amplitudes.

Figs. 3(b) and 3(c) show EDX line scan results (not normalized) comparing $\mathrm{Ti}_{0.31} \mathrm{Cr}_{0.07} \mathrm{Al}_{0.62} \mathrm{~N} / \mathrm{TiN}$ and $\mathrm{Ti}_{0.31} \mathrm{Cr}_{0.07} \mathrm{Al}_{0.62} \mathrm{~N} / \mathrm{Ti}_{0.1} \mathrm{Cr}_{0.9} \mathrm{~N}$ in their as deposited states and at $1100^{\circ} \mathrm{C}$.

At $1100^{\circ} \mathrm{C}$, there is segregation of $\mathrm{Ti}$ and $\mathrm{Al}$ in both samples. The segregation is more pronounced in terms of higher compositional amplitudes at 1100 and $1200^{\circ} \mathrm{C} \mathrm{com-}$ pared to $900^{\circ} \mathrm{C}$ (not shown). For $\mathrm{Ti}_{0.31} \mathrm{Cr}_{0.07} \mathrm{Al}_{0.62} \mathrm{~N} /$ $\mathrm{Ti}_{0.1} \mathrm{Cr}_{0.9} \mathrm{~N}$, Fig. 3(c), Ti atoms have relocated to the initially $\mathrm{Cr}$-rich layer and $\mathrm{Cr}$ atoms have relocated to the Al-rich layer. TiN and $\mathrm{CrN}$ are soluble at high temperatures ${ }^{10}$ which means that by the shift of the $\mathrm{Ti}$ and $\mathrm{Cr}$ positions in the layers the total energy is decreased since the mixing enthalpy between $\mathrm{TiN}$ and $\mathrm{AlN}$ is higher than between $\mathrm{CrN}$ and AlN. ${ }^{18}$ With the $\mathrm{Cr}$ atoms more evenly distributed in the layers compared to the as deposited state the coherency strain between the Ti- and Al-rich c-TiCrAlN layers is decreased and the driving force for spinodal decomposition is also decreased. ${ }^{10}$ In summary, the initial Cr-content (x) affects the composition of the decomposed products. $\mathrm{Ti}_{0.31} \mathrm{Cr}_{0.07} \mathrm{Al}_{0.62} \mathrm{~N} / \mathrm{TiN}$ multilayer coating decomposes into $c$-(TiCr)AlN/c-TiCr(Al)N whereas $\mathrm{Ti}_{0.31} \mathrm{Cr}_{0.07} \mathrm{Al}_{0.62} \mathrm{~N} /$ $\mathrm{Ti}_{0.1} \mathrm{Cr}_{0.9} \mathrm{~N}$ decomposes into $c$ - $(\mathrm{Ti}) \mathrm{CrAlN} / c-\mathrm{TiCr}(\mathrm{Al}) \mathrm{N}$ containing $\mathrm{Cr}$ in both phases (elements within parentheses indicate a low content). However, as will be demonstrated and discussed from here on, the diffusion during the decomposition process is also affected by the initial strain. a) $\mathrm{Ti}_{0.31} \mathrm{Cr}_{0.07} \mathrm{Al}_{0.62} \mathrm{~N} / \mathrm{TiN}$

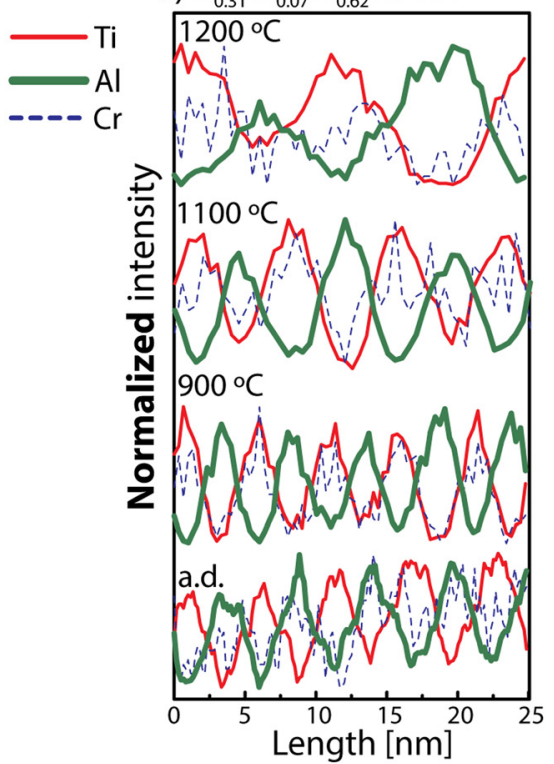

b) $\mathrm{Ti}_{0.31} \mathrm{Cr}_{0.07} \mathrm{Al}_{0.62} \mathrm{~N} / \mathrm{TiN}$
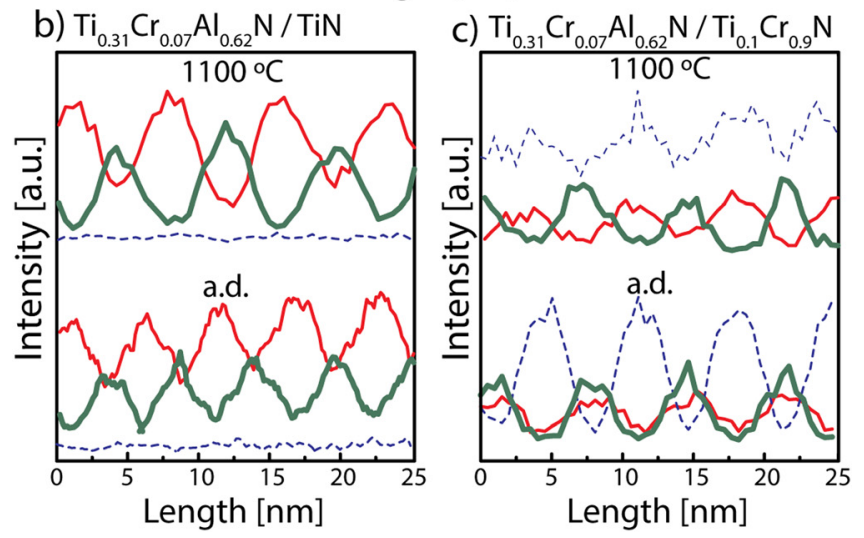

FIG. 3. EDX line scans with normalized intensity from $\mathrm{Ti}_{0.31} \mathrm{Cr}_{0.07} \mathrm{Al}_{0.62} \mathrm{~N} /$ TiN as deposited and at 900,1100 , and $1200^{\circ} \mathrm{C}$. (b) and (c) Line scans (not normalized) from $\mathrm{Ti}_{0.31} \mathrm{Cr}_{0.07} \mathrm{Al}_{0.62} \mathrm{~N} / \mathrm{TiN}$ and $\mathrm{Ti}_{0.31} \mathrm{Cr}_{0.07} \mathrm{Al}_{0.62} \mathrm{~N}$ / $\mathrm{Ti}_{0.1} \mathrm{Cr}_{0.9} \mathrm{~N}$ as deposited and at $1100^{\circ} \mathrm{C}$, respectively.

Fig. 4(a) shows a high-resolution micrograph of the $\mathrm{Ti}_{0.31} \mathrm{Cr}_{0.07} \mathrm{Al}_{0.62} \mathrm{~N} / \mathrm{TiN}$ coating annealed at $1100^{\circ} \mathrm{C}$. This sample has the highest coherency strain and the structure is cubic and coherent across the layers (observed for all studied coatings at $1100^{\circ} \mathrm{C}$ ). The coherency across the domains is consistent with iso-structural (spinodal) decomposition. ${ }^{31}$

Figs. 4(b) and 4(c) show results from 2-dimensional EDX mapping obtained after annealing at $1100{ }^{\circ} \mathrm{C}$ of $\mathrm{Ti}_{0.31} \mathrm{Cr}_{0.07} \mathrm{Al}_{0.62} \mathrm{~N} / \mathrm{TiN}$ and $\mathrm{Ti}_{0.31} \mathrm{Cr}_{0.07} \mathrm{Al}_{0.62} \mathrm{~N} / \mathrm{Ti}_{0.1} \mathrm{Cr}_{0.9} \mathrm{~N}$, respectively. The characteristic $\mathrm{x}$-ray signals from $\mathrm{Ti}, \mathrm{Cr}$, and $\mathrm{Al}$ have been plotted separately. The domain size of the $\mathrm{Al}$ - and Ti-enriched domains is $\sim 5 \mathrm{~nm}$, i.e., significantly smaller compared to the $\mathrm{Ti}_{0.31} \mathrm{Cr}_{0.07} \mathrm{Al}_{0.62} \mathrm{~N}$ non-layered coating ( $\sim 20 \mathrm{~nm}$ in Ref. 19 not shown here). From the maps, it is clear that the diffusion of the metallic elements has taken different paths in the two samples. For $\mathrm{Ti}_{0.31} \mathrm{Cr}_{0.07} \mathrm{Al}_{0.62} \mathrm{~N} / \mathrm{TiN}$, Fig. 4(b), where the coherency strain is higher, the diffusion has occurred both perpendicular and parallel to the growth direction. The multilayer structure is thus partially dissolved and now contains different domains which coarsen in all directions. This resembles an isotropic coarsening similar to what has been observed in 

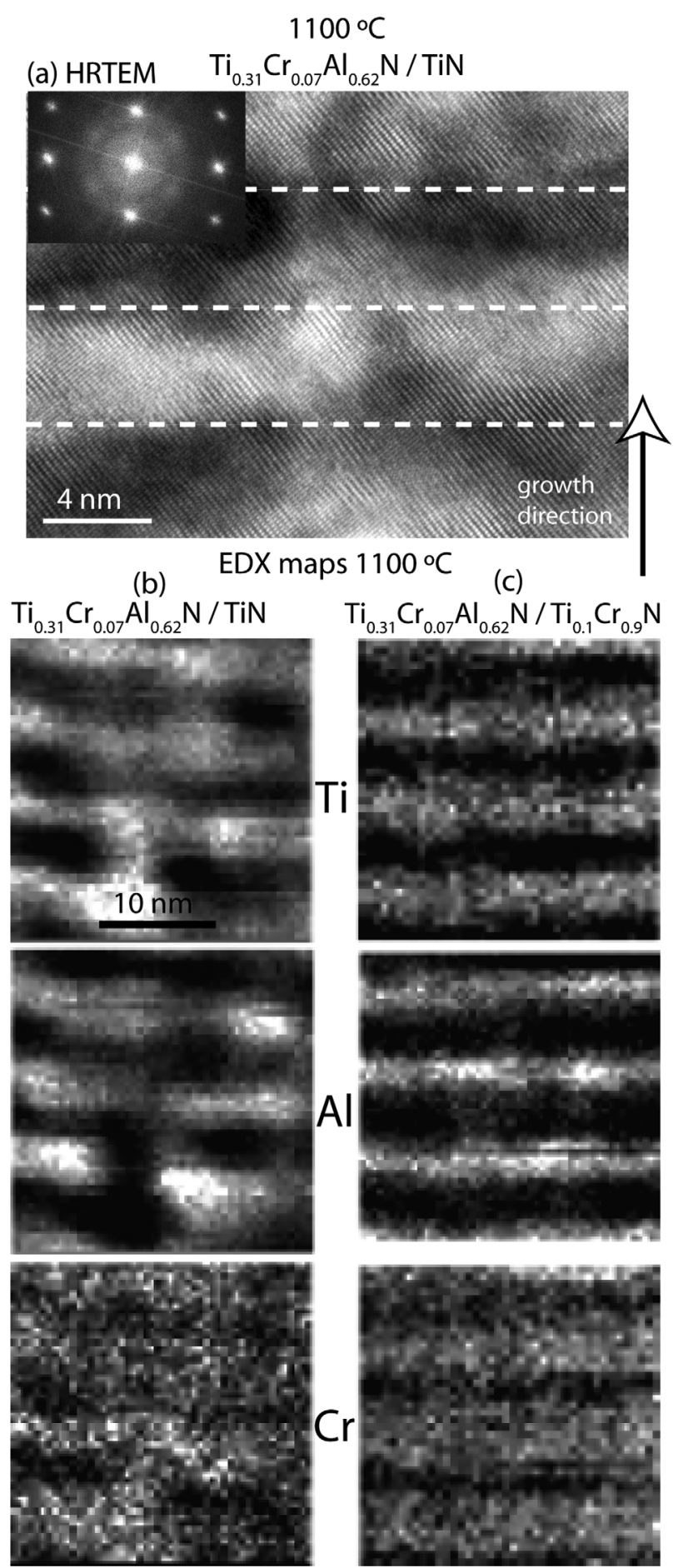

FIG. 4. (a) High resolution TEM with its FFT of $\mathrm{Ti}_{0.31} \mathrm{Cr}_{0.07} \mathrm{Al}_{0.62} \mathrm{~N} / \mathrm{TiN}$. (b) and (c) EDX maps of $\mathrm{Ti}_{0.31} \mathrm{Cr}_{0.07} \mathrm{Al}_{0.62} \mathrm{~N} / \mathrm{TiN}$ and $\mathrm{Ti}_{0.31} \mathrm{Cr}_{0.07} \mathrm{Al}_{0.62} \mathrm{~N} /$ $\mathrm{Ti}_{0.1} \mathrm{Cr}_{0.9} \mathrm{~N}$ annealed at $1100^{\circ} \mathrm{C}$, respectively.

TiAlN/TiN multilayer coatings. ${ }^{8}$ The coarsened structure also results in what appears as increased layer thicknesses in the EDX line scans Fig. 3(a) but it is an effect of the larger domains.

In contrast to an isotropic coarsening, the layer interfaces are more distinct for $\mathrm{Ti}_{0.31} \mathrm{Cr}_{0.07} \mathrm{Al}_{0.62} \mathrm{~N} / \mathrm{Ti}_{0.1} \mathrm{Cr}_{0.9} \mathrm{~N}$, seen in Fig. 4(c). For this sample, the coherency strain is lower and the diffusion on the metallic sublattice has predominately taken place perpendicular to the layers (in the growth direction) maintaining a distinct layered structure. This resembles an interface-directed decomposition similar to observations in TiAlN/CrN multilayer coatings. ${ }^{32}$

Simulations on spinodal decomposition in other material systems $^{33-35}$ and in particular for TiAlN/TiN multilayers ${ }^{31}$ have shown that the decomposed microstructure may contain a compositional wave proceeding perpendicular to the interface depending on initial conditions such as atomic clustering. Atomic clustering reduces the number of Ti-Al bonds and consequently the driving force for spinodal decomposition is decreased. ${ }^{36}$ The addition of $\mathrm{Cr}$ in TiAlN coatings also decrease the driving force for spinodal decomposition but these effects are true for a solid solution and should not be confused with the alternation of the $\mathrm{Cr}$-content discussed here. The evolved microstructure of the coatings in this work is altered by the coherency strain caused by the surrounding $\mathrm{Ti}_{1-\mathrm{x}} \mathrm{Cr}_{\mathrm{x}} \mathrm{N}$ layer, which in turn is controlled by the Cr-content (x). Similarly, the formation of a compositional wave perpendicular to the interface or an anisotropic microstructure occurs in coatings under strain caused by the substrate resulting in elastic energy which is also compositional dependent. ${ }^{34,37-39}$

Phase identification using XRD of these polycrystalline multilayer coatings is a complex task due to closely located peaks in combination with the small size (few nanometers) of the domains formed during the decomposition process that makes the peaks broad and overlapping. However, when the results are combined with lattice resolved TEM studies measuring the relative plane spacing, the present phases are conclusively identified.

Fig. 5 shows $x$-ray diffractograms in the $2 \theta$ range from $32^{\circ}$ to $45^{\circ}$ of as deposited $\mathrm{Ti}_{0.31} \mathrm{Cr}_{0.07} \mathrm{Al}_{0.62} \mathrm{~N} / \mathrm{TiN}$ and $\mathrm{Ti}_{0.31} \mathrm{Cr}_{0.07} \mathrm{Al}_{0.62} \mathrm{~N} / \mathrm{Ti}_{0.1} \mathrm{Cr}_{0.9} \mathrm{~N}$, and after annealing at 800 , 900,1000 , and $1100^{\circ} \mathrm{C}$.

For as deposited $\mathrm{Ti}_{0.31} \mathrm{Cr}_{0.07} \mathrm{Al}_{0.62} \mathrm{~N} / \mathrm{TiN}$, peaks at $2 \theta \approx 37^{\circ}$ and $43.1^{\circ}$ are detected corresponding to $c$-TiCrAlN (average spacing of $c-\mathrm{Ti}_{0.31} \mathrm{Cr}_{0.07} \mathrm{Al}_{0.62} \mathrm{~N}+c$-TiN). These peaks are shifted to higher angles when annealed at $800^{\circ} \mathrm{C}$ which indicate stress relaxation and crystal recovery processes (such as annihilation of defects including interstitials of metallic species, nitrogen atoms, and vacancies expected to be present in arc evaporated coatings ${ }^{40}$ ). There are two contributing factors for the appearance of superlattice reflections at 800 and $900{ }^{\circ} \mathrm{C}$, seen for example at $2 \theta \approx 36.1^{\circ}$. The crystal recovery processes increase the strength of second order reflections and after annealing, there is a decreased layer intermixing as a consequence of the spinodal decomposition segregating $\mathrm{Ti}$ and $\mathrm{Al}$ seen in TEM, which results in more distinct layering and consequently stronger super lattice reflections. Quantitative determination of the width of the layer interfaces based on EDX is affected by probe projection errors. Despite this uncertainty, when comparing the average slopes of the $\mathrm{Ti}$ and Al signals (the layer intermixing) in Fig. 3(a) for the as deposited and the $900{ }^{\circ} \mathrm{C}$ annealed samples, $\sim 8 \%$ steeper slope is seen for the annealed sample. At 1000 and $1100^{\circ} \mathrm{C}$, the superlattice reflections have disappeared due to the domain coarsening and the deterioration of the layered structure.

A peak detected at $2 \theta \approx 44^{\circ}$ appears when annealed at $800^{\circ} \mathrm{C}$ and it remains visible up to $1100^{\circ} \mathrm{C}$. This peak corresponds to $\mathrm{Co}$, which is used as the binder in the substrates. 

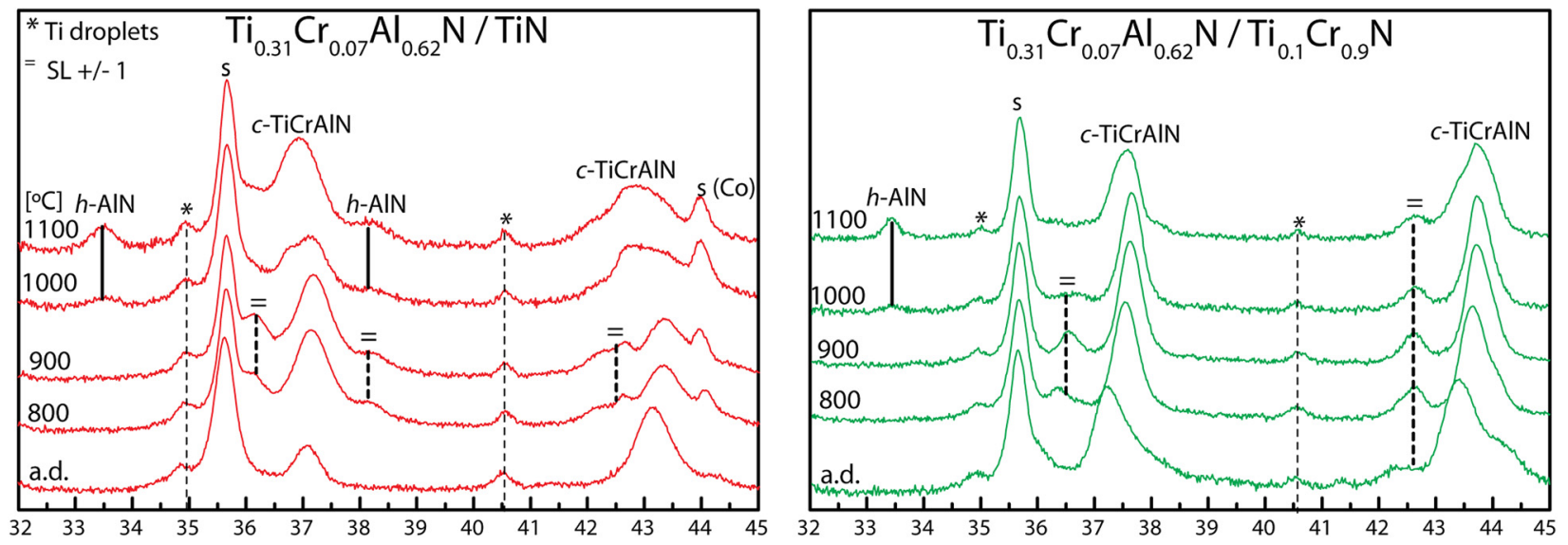

FIG. 5. X-ray diffractograms of $\mathrm{Ti}_{0.31} \mathrm{Cr}_{0.07} \mathrm{Al}_{0.62} \mathrm{~N} / \mathrm{TiN}$ and $\mathrm{Ti}_{0.31} \mathrm{Cr}_{0.07} \mathrm{Al}_{0.62} \mathrm{~N} / \mathrm{Ti}_{0.1} \mathrm{Cr}_{0.9} \mathrm{~N}$ as deposited and at $800,900,1000$, and $1100{ }^{\circ} \mathrm{C}$.

From the TEM investigation it was seen that the TiN buffer layer effectively prevents Co diffusion into the coating.

Above $900{ }^{\circ} \mathrm{C}$, the $c$-TiCrAlN peaks are broadened which is consistent with iso-structural decomposition (spinodal decomposition) of TiCrAlN. ${ }^{10,19}$

For $\mathrm{Ti}_{0.31} \mathrm{Cr}_{0.07} \mathrm{Al}_{0.62} \mathrm{~N} / \mathrm{Ti}_{0.1} \mathrm{Cr}_{0.9} \mathrm{~N}$, Fig. 5(b), there are two asymmetric $c$-TiCrAlN peaks (average spacing of $\left.c-\mathrm{Ti}_{0.31} \mathrm{Cr}_{0.07} \mathrm{Al}_{0.62} \mathrm{~N}+c-\mathrm{Ti}_{0.1} \mathrm{Cr}_{0.9} \mathrm{~N}\right)$ in the as deposited state, seen at $2 \theta \approx 37.2^{\circ}$ and $44.2^{\circ}$. At $800^{\circ} \mathrm{C}$, the asymmetry becomes less pronounced and the coating peaks shift to higher angles due to crystal recovery and stress relaxation. Superlattice reflections are detected at $800^{\circ} \mathrm{C}$ up to $1100^{\circ} \mathrm{C}$ consistent with the maintained layered structure seen in z-contrast STEM. At $1000^{\circ} \mathrm{C}$, the $c$-TiCrAlN peaks still appear as single peaks (average spacing of the multilayer structure) and do not show the same pronounced broadening as for $\mathrm{Ti}_{0.31} \mathrm{Cr}_{0.07} \mathrm{Al}_{0.62} \mathrm{~N} / \mathrm{TiN}$.

At $1100{ }^{\circ} \mathrm{C}$, there is an asymmetric broadening originating from iso-structural decomposition into $\mathrm{Ti}$ and Al-enriched TiCrAlN domains. This broadening is less pronounced compared to the $\mathrm{Ti}_{0.31} \mathrm{Cr}_{0.07} \mathrm{Al}_{0.62} \mathrm{~N} / \mathrm{TiN}$ coating.

For both samples a peak at $2 \theta \approx 33.2^{\circ}$ corresponding to $h$-AlN is detected at 1000 and $1100^{\circ} \mathrm{C}$. This is due to the formation and growth of $h$-AlN precipitates in the grain

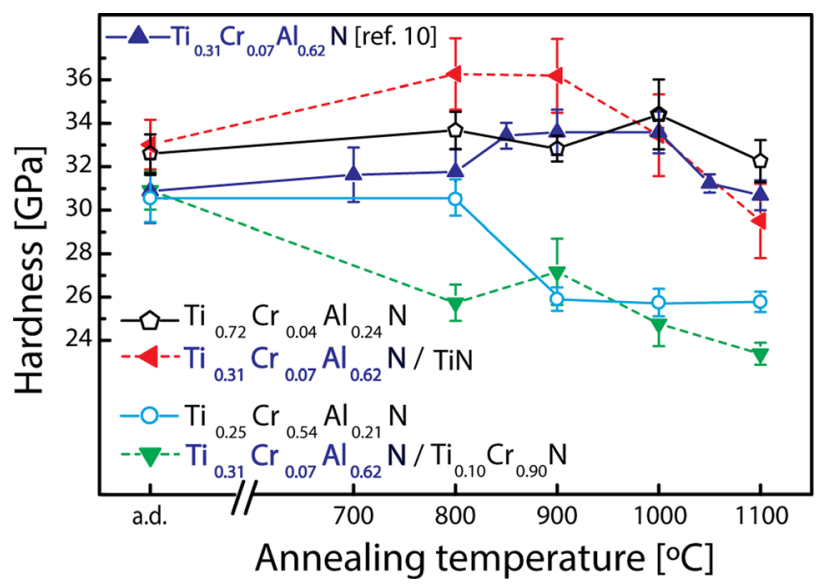

FIG. 6. Hardness versus annealing temperature of two multilayer coatings $\mathrm{Ti}_{0.31} \mathrm{Cr}_{0.07} \mathrm{Al}_{0.62} \mathrm{~N} / \mathrm{TiN}$ and $\mathrm{Ti}_{0.31} \mathrm{Cr}_{0.07} \mathrm{Al}_{0.62} \mathrm{~N} / \mathrm{Ti}_{0.1} \mathrm{Cr}_{0.9} \mathrm{~N}$ as well as three monolithic coatings with compositions of $\mathrm{Ti}_{0.31} \mathrm{Cr}_{0.07} \mathrm{Al}_{0.62} \mathrm{~N}$, $\mathrm{Ti}_{0.72} \mathrm{Cr}_{0.04} \mathrm{Al}_{0.24} \mathrm{~N}$, and $\mathrm{Ti}_{0.25} \mathrm{Cr}_{0.54} \mathrm{Al}_{0.21} \mathrm{~N}$. boundaries seen by TEM (see Fig. 8). The cubic structure within the grain interiors is thus stable up to $1100^{\circ} \mathrm{C}$ in both samples. This is an improved retention and stabilization of the cubic structure compared to monolith $\mathrm{Ti}_{0.31} \mathrm{Cr}_{0.07} \mathrm{Al}_{0.62} \mathrm{~N}$. ${ }^{19}$ This is achieved due to the confinement of the coarsening enforced by the multilayered structure. The smaller size of the Al-rich domains favors the cubic coherent structure even at this high temperature similar to the observations in TiAlN/TiN multilayer coatings. ${ }^{8,9}$

\section{B. Hardness versus annealing temperature}

Fig. 6 shows the hardness versus annealing temperatures up to $1100^{\circ} \mathrm{C}$ of the multilayer coatings $\mathrm{Ti}_{0.31} \mathrm{Cr}_{0.07} \mathrm{Al}_{0.62} \mathrm{~N} /$ TiN and $\mathrm{Ti}_{0.31} \mathrm{Cr}_{0.07} \mathrm{Al}_{0.62} \mathrm{~N} / \mathrm{Ti}_{0.1} \mathrm{Cr}_{0.9} \mathrm{~N}$. It also contains the hardness of three monolithic coatings with the compositions of $\mathrm{Ti}_{0.31} \mathrm{Cr}_{0.07} \mathrm{Al}_{0.62} \mathrm{~N}$ (Refs. 10 and 19 ), $\mathrm{Ti}_{0.72} \mathrm{Cr}_{0.04} \mathrm{Al}_{0.24} \mathrm{~N}$, and $\mathrm{Ti}_{0.25} \mathrm{Cr}_{0.54} \mathrm{Al}_{0.21} \mathrm{~N}$. The two latter were deposited for the purpose of comparison. Their compositions approximately correspond to the average compositions of the multilayer coatings, $\quad \mathrm{Ti}_{0.31} \mathrm{Cr}_{0.07} \mathrm{Al}_{0.62} \mathrm{~N} / \mathrm{TiN}$ and $\mathrm{Ti}_{0.31} \mathrm{Cr}_{0.07} \mathrm{Al}_{0.62} \mathrm{~N} /$ $\mathrm{Ti}_{0.1} \mathrm{Cr}_{0.9} \mathrm{~N}$, respectively.

In the as deposited state the hardness of the coatings is similar but the coatings with highest Ti-content

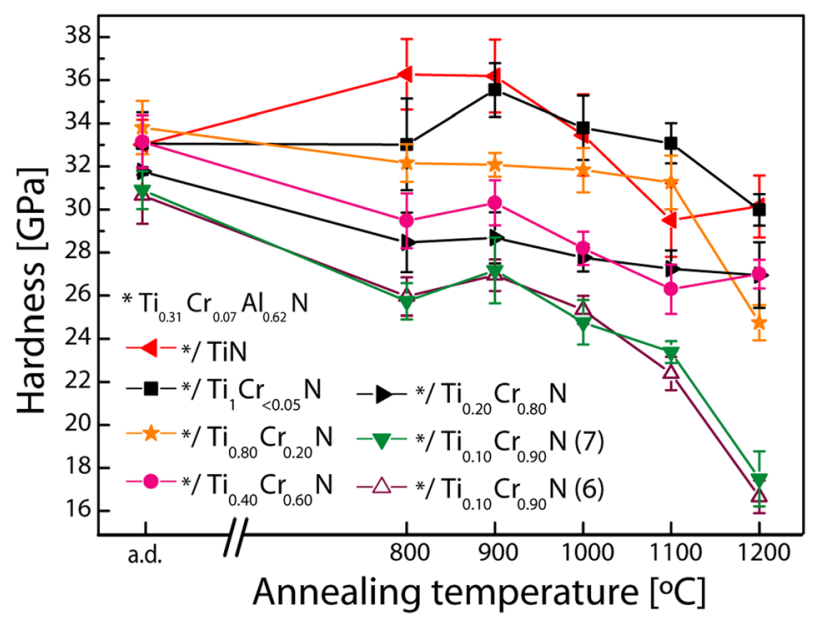

FIG. 7. Hardness versus annealing temperature of the multilayer coatings $\mathrm{Ti}_{0.31} \mathrm{Cr}_{0.07} \mathrm{Al}_{0.62} \mathrm{~N} / \mathrm{Ti}_{1-\mathrm{x}} \mathrm{Cr}_{\mathrm{x}} \mathrm{N}$ ranging from $\mathrm{x}=0$ (TiN) and $\mathrm{x}=0.9$ $\left(\mathrm{Ti}_{0.1} \mathrm{Cr}_{0.9} \mathrm{~N}\right)$. 
STEM z-contrast $1100^{\circ} \mathrm{C}$

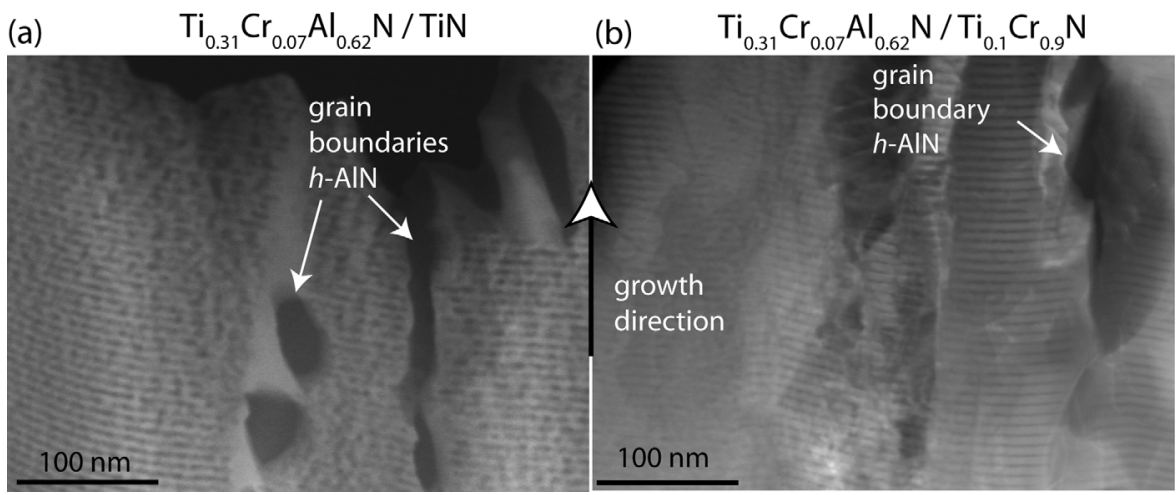

FIG. 8. STEM z-contrast micrographs of $\mathrm{Ti}_{0.31} \mathrm{Cr}_{0.07} \mathrm{Al}_{0.62} \mathrm{~N} / \mathrm{TiN}$ (a) and $\mathrm{Ti}_{0.31} \mathrm{Cr}_{0.07} \mathrm{Al}_{0.62} \mathrm{~N} / \mathrm{Ti}_{0.1} \mathrm{Cr}_{0.9} \mathrm{~N}$ annealed at $1100^{\circ} \mathrm{C}$.
$\left(\mathrm{Ti}_{0.31} \mathrm{Cr}_{0.07} \mathrm{Al}_{0.62} \mathrm{~N} / \mathrm{TiN}\right.$ and $\left.\mathrm{Ti}_{0.72} \mathrm{Cr}_{0.04} \mathrm{Al}_{0.24} \mathrm{~N}\right)$ have a hardness of $\sim 31 \mathrm{GPa}$ and are slightly harder $(\sim 10 \%)$.

When annealed at 800 and $900{ }^{\circ} \mathrm{C}$, there is a significant hardness increase for $\mathrm{Ti}_{0.31} \mathrm{Cr}_{0.07} \mathrm{Al}_{0.62} \mathrm{~N} / \mathrm{TiN}$ that is more pronounced in comparison to the monoliths $\mathrm{Ti}_{0.31} \mathrm{Cr}_{0.07} \mathrm{Al}_{0.62} \mathrm{~N}$ and $\mathrm{Ti}_{0.72} \mathrm{Cr}_{0.04} \mathrm{Al}_{0.24} \mathrm{~N}$. In contrast to this, the multilayer coating $\mathrm{Ti}_{0.31} \mathrm{Cr}_{0.07} \mathrm{Al}_{0.62} \mathrm{~N} / \mathrm{Ti}_{0.1} \mathrm{Cr}_{0.9} \mathrm{~N}$ shows a significant hardness decrease that is more pronounced compared to the same monoliths.

At higher temperatures between 900 and $1100{ }^{\circ} \mathrm{C}$, the coatings with highest $\mathrm{Cr}$-content have the lowest hardness in accordance with previously published data. ${ }^{11}$ At $1100{ }^{\circ} \mathrm{C}$, the hardness of the $\mathrm{Ti}_{0.31} \mathrm{Cr}_{0.07} \mathrm{Al}_{0.62} \mathrm{~N} / \mathrm{TiN}$ multilayer has decreased to the same level as the other two high Ti-containing monoliths whereas the hardness of the high Cr-containing coatings is significantly lower.

The formation of coherent $c-(\mathrm{TiCr}) \mathrm{AlN}$ and $c-\mathrm{TiCr}(\mathrm{Al}) \mathrm{N}$ domains introduces new domain boundaries apart from the multilayer interfaces present in the as deposited state. At these new boundaries coherency stresses are generated resulting in an age hardening similar to the observations in monolith $c$-TiAlN ${ }^{4,5,41}$ and multilayer $c$-TiAlN $/ c-\mathrm{TiN}^{8,9}$ coatings. Due to the presence of multilayer interfaces in TiAlN/TiN coatings the onset of the spinodal decomposition is shifted to lower temperatures through the phenomenon of surface directed spinodal decomposition. ${ }^{31}$ Here, this is experimentally supported by the observed decreased layer intermixing (generating super lattice reflections) and the hardness increase which both are caused by the spinodal decomposition occurring at a lower temperature for $\mathrm{Ti}_{0.31} \mathrm{Cr}_{0.07} \mathrm{Al}_{0.62} \mathrm{~N} /$ TiN compared to the non-layered coating. The hardness is also more pronounced due to the increased strain. In $\mathrm{Ti}_{0.31} \mathrm{Cr}_{0.07} \mathrm{Al}_{0.62} \mathrm{~N} / \mathrm{TiN}$, the strain is the highest and an applied strain is known to promote the spinodal decomposition $^{42,43}$ and to suppress the formation $h$-AlN. ${ }^{4,45}$

Fig. 7 shows the hardness versus annealing temperatures up to $1200{ }^{\circ} \mathrm{C}$ of the multilayer coatings studied in this work. The Cr-content $(\mathrm{x})$ ranges from $\mathrm{x}=0(\mathrm{TiN})$ to $\mathrm{x}=0.9$ $\left(\mathrm{Ti}_{0.1} \mathrm{Cr}_{0.9} \mathrm{~N}\right)$. From here on, when mentioning the $\mathrm{Cr}$-content, it is referred to content of the $\mathrm{Ti}_{1-\mathrm{x}} \mathrm{Cr}_{\mathrm{x}} \mathrm{N}$ layer $(\mathrm{x})$.

In the as deposited states the hardness of all coatings are around $\sim 32 \mathrm{GPa}$ but slightly lower $(<10 \%)$ for the coatings with high $\mathrm{Cr}$-content $(0.8<\mathrm{x}<0.9)$.

When the coatings are annealed at $800{ }^{\circ} \mathrm{C}$, above the deposition temperature, differences between the coatings become clear. Coatings with 20 or more at. $\% \mathrm{Cr}$-content show no significant hardness increase. In fact, above 40 at. $\%$ the hardness is significantly decreased. This is in contrast to the coatings with 5 or less at. $\% \mathrm{Cr}(\mathrm{x}<=0.05)$ where there is a significant hardness increase.

After annealing at $1100{ }^{\circ} \mathrm{C}$, the coating with 5 at. $\% \mathrm{Cr}$ $\left(\mathrm{Ti}_{0.31} \mathrm{Cr}_{0.07} \mathrm{Al}_{0.62} \mathrm{~N} / \mathrm{Ti}_{0.95} \mathrm{Cr}_{0.05} \mathrm{~N}\right)$ shows the highest hardness while the coatings with 90 at. $\% \mathrm{Cr}(\mathrm{x}=0.9)$ have a significantly lower hardness.

After annealing at $1200{ }^{\circ} \mathrm{C}$, the hardness is highest for Cr-contents up to 5 at. $\% \quad(\mathrm{x}<=0.05)$, slightly lower $(\sim 10 \%)$ for Cr-contents between 20 and 80 at. $\%$ $(0.2<\mathrm{x}<0.8)$ and significantly lower for a $\mathrm{Cr}$-content of 90 at. $\%(\mathrm{x}=0.9)$.

For $\mathrm{Ti}_{0.3} \mathrm{Al}_{0.7} \mathrm{~N} / \mathrm{CrN}$ multilayer coatings an enhancement of the hardness has been demonstrated and has been attributed to the elastic mismatch rather than the lattice parameter mismatch. ${ }^{23}$ Here, however, the hardness is strongly related to the coherency strain both in the as deposited state between the multilayers and at higher annealing temperatures between the $\mathrm{Ti}$ - and Al-rich domains formed during the decomposition. For $\mathrm{Ti}_{0.31} \mathrm{Cr}_{0.07} \mathrm{Al}_{0.62} \mathrm{~N} / \mathrm{TiN}(\mathrm{x}=0)$, the lattice mismatches are the highest therefore the hardness is slightly higher in the as deposited state. The hardness increase is also more pronounced during the spinodal decomposition due to the higher strain between the decomposed domains. When adding more $\mathrm{Cr}$ (increasing $\mathrm{x}$ ), the lattice mismatch is reduced between the multilayers and the hardness is slightly less as deposited. Upon annealing, the $\mathrm{Cr}$ atoms redistribute almost evenly in the coating reducing the strain between the Ti- and Al-rich generating lower coherency stresses and a lower hardness. The reduction of the hardness and the strain between the Ti- and Al-rich domains are is to the observations in monolith TiAlN coatings alloyed with $\mathrm{Cr}$ (Ref. 19) domains (the lattice parameter of $c-\mathrm{CrN}$ is in-between $c$-TiN and $c$-AlN ${ }^{18}$ ).

Figs. 8(a) and 8(b) show Z-contrast image of $\mathrm{Ti}_{0.31} \mathrm{Cr}_{0.07} \mathrm{Al}_{0.62} \mathrm{~N} / \mathrm{TiN}$ and $\mathrm{Ti}_{0.31} \mathrm{Cr}_{0.07} \mathrm{Al}_{0.62} \mathrm{~N} / \mathrm{Ti}_{0.1} \mathrm{Cr}_{0.9} \mathrm{~N}$ annealed at $1100^{\circ} \mathrm{C}$, respectively. Once again it can be seen that the layers appear to be dissolving and are no longer sharp as a result of the isotropic coarsening in $\mathrm{Ti}_{0.31} \mathrm{Cr}_{0.07} \mathrm{Al}_{0.62} \mathrm{~N} / \mathrm{TiN}$ and for $\mathrm{Ti}_{0.31} \mathrm{Cr}_{0.07} \mathrm{Al}_{0.62} \mathrm{~N} /$ $\mathrm{Ti}_{0.1} \mathrm{Cr}_{0.9} \mathrm{~N}$ the layer interfaces are more distinct, (b). There is also a formation of $h$-AlN at the grain boundaries and the $h$-AlN precipitates are incoherent with the surrounding cubic 
structure (confirmed with lattice resolved TEM). The precipitates are approximately $40 \%$ larger in $\mathrm{Ti}_{0.31} \mathrm{Cr}_{0.07} \mathrm{Al}_{0.62} \mathrm{~N} /$ $\mathrm{Ti}_{0.1} \mathrm{Cr}_{0.9} \mathrm{~N}$ (b), compared to in $\mathrm{Ti}_{0.31} \mathrm{Cr}_{0.07} \mathrm{Al}_{0.62} \mathrm{~N} / \mathrm{TiN}$ (a) (determined by cross sectional TEM). Hardness is measured at a global level, which means that the relatively large hardness differences between the samples at the higher annealing temperatures are not entirely caused by the different stress states in the cubic structure within the grains. Incoherent $h$-AlN in the grain boundaries is known to be detrimental in terms of hardness (for example, in $\mathrm{CrAlN}^{46}$ and $\operatorname{TiAlN}^{5}$ ). There is obviously more $\mathrm{Cr}$ present in the decomposed domains in the coatings with higher initial Cr-content (x) (see EDX line scans Figs. 3(b) and 3(c)). This decreases the mixing enthalpy and the driving force for spinodal decomposition ${ }^{10}$ which in turn increases the critical radius required for homogenous domain growth. ${ }^{47}$ The result is a prolonged development of the compositional amplitude during the spinodal decomposition resulting in smaller domain sizes upon annealing. ${ }^{19}$ This promotes the other competing decomposition process, which in the TiCrAlN system is heterogeneous $h$-AlN precipitation in the grain boundaries. ${ }^{11}$

\section{CONCLUSIONS}

$c-\mathrm{Ti}_{0.31} \mathrm{Cr}_{0.07} \mathrm{Al}_{0.62} \mathrm{~N} / c-\mathrm{Ti}_{1-\mathrm{x}} \mathrm{Cr}_{\mathrm{x}} \mathrm{N}$ multilayer coatings are unstable and undergo spinodal decomposition into Ti- and Al-rich TiCrAlN domains. The hardness and the metallic diffusion during the decomposition can be altered by controlling the coherency strain through the Cr-content (x). The hardness in the as deposited states decreases with increasing $\mathrm{x}$ due to lower coherency strain. For $\mathrm{x}=0$, there is a significant hardness increase during the spinodal decomposition. The hardness increase is higher and initiates at a lower temperature of $800^{\circ} \mathrm{C}$ compared to the monolith $\mathrm{Ti}_{0.31} \mathrm{Cr}_{0.07} \mathrm{Al}_{0.62} \mathrm{~N}$. This is due to surface directed spinodal decomposition, higher coherency strain, and an improved stability of the cubic structure. A higher $\mathrm{Cr}$-content, $\mathrm{x}=0.9$, generates lower coherency strain. The hardness decreases significantly upon annealing above $800^{\circ} \mathrm{C}$ partially due to the lower coherency strain but also a more pronounced $h$-AlN precipitation in the grain boundaries. With a higher initial strain, the developed microstructure during the decomposition is more isotropic. With a lower strain, the diffusion occurs perpendicular to the multilayers retaining the multilayered structure.

\section{ACKNOWLEDGMENTS}

This work was supported by the SSF project Designed multicomponent coatings, MultiFilms. We would like to acknowledge Dr. M. P. Johansson Jöesaar at Seco Tools AB for support with the depositions.

${ }^{1}$ R. M'Saoubi, C. Le Calvez, B. Changeux, and J. L. Lebrun, Proc. Inst. Mech. Eng., Part B 216(2), 153 (2002).

${ }^{2}$ M. A. Davies, T. Ueda, R. M'Saoubi, B. Mullany, and A. L. Cooke, CIRP Ann. Manuf. Technol. 56(2), 581 (2007).

${ }^{3}$ A. Knutsson, J. Ullbrand, L. Rogström, N. Norrby, L. J. S. Johnson, L. Hultman, J. Almer, M. P. Johansson Jöesaar, B. Jansson, and M. Odén, J. Appl. Phys. 113(21), 213518 (2013).

${ }^{4}$ P. H. Mayrhofer, A. Hörling, L. Karlsson, J. Sjölén, T. Larsson, C. Mitterer, and L. Hultman, Appl. Phys. Lett. 83(10), 2049 (2003).
${ }^{5}$ A. Hörling, L. Hultman, M. Odén, J. Sjölén, and L. Karlsson, Surf. Coat. Technol. 191(2-3), 384 (2005).

${ }^{6}$ M. Odén, L. Rogström, A. Knutsson, M. R. Terner, P. Hedström, J. Almer, and J. Ilavsky, Appl. Phys. Lett. 94(5), 053114 (2009).

${ }^{7}$ A. Knutsson, M. P. Johansson, L. Karlsson, and M. Odén, Surf. Coat. Technol. 205(16), 4005 (2011).

${ }^{8}$ A. Knutsson, M. P. Johansson, L. Karlsson, and M. Odén, J. Appl. Phys. 108(4), 044312 (2010).

${ }^{9}$ A. Knutsson, M. P. Johansson, P. O. Å Persson, L. Hultman, and M. Odén, Appl. Phys. Lett. 93(14), 143110-143113 (2008).

${ }^{10}$ H. Lind, R. Forsén, B. Alling, N. Ghafoor, F. Tasnádi, M. P. Johansson, I. A. Abrikosov, and M. Odén, Appl. Phys. Lett. 99(9), 091903 (2011).

${ }^{11}$ R. Forsén, M. P. Johansson, M. Odén, and N. Ghafoor, Thin Solid Films 534, 394-402 (2013).

${ }^{12}$ Q. Luo, W. M. Rainforth, L. A. Donohue, I. Wadsworth, and W. Münz, Vacuum 53(1-2), 123 (1999).

${ }^{13}$ A. E. Santana, A. Karimi, V. H. Derflinger, and A. Schütze, Surf. Coat. Technol. 177-178, 334-340 (2004).

${ }^{14}$ H. W. Hugosson, H. Högberg, M. Algren, M. Rodmar, and T. I. Selinder, J. Appl. Phys. 93(8), 4505-4511 (2003).

${ }^{15}$ S. G. Harris, E. D. Doyle, A. C. Vlasveld, J. Audy, J. M. Long, and D. Quick, Wear 254(1-2), 185 (2003).

${ }^{16}$ Z. F. Zhou, P. L. Tam, P. W. Shum, and K. Y. Li, Thin Solid Films 517(17), 5243-5247 (2009).

${ }^{17}$ A. I. Kovalev, D. L. Wainstein, A. Y. Rashkovskiy, G. S. Fox-Rabinovich, K. Yamamoto, S. Veldhuis, M. Aguirre, and B. D. Beake, Vacuum 84(1), 184-187 (2009).

${ }^{18}$ B. Alling, T. Marten, I. A. Abrikosov, and A. Karimi, J. Appl. Phys. 102(4), 044314 (2007).

${ }^{19}$ R. Forsén, M. Johansson, M. Odén, and N. Ghafoor, J. Vac. Sci. Technol. A 30(6), 061506 (2012).

${ }^{20}$ L. Hultman, G. Håkansson, U. Wahlström, J. Sundgren, I. Petrov, F. Adibi, and J. E. Greene, Thin Solid Films 205(2), 153 (1991).

${ }^{21}$ G. Abadias, A. Michel, C. Tromas, C. Jaouen, and S. N. Dub, Surf. Coat. Technol. 202(4-7), 844-853 (2007).

${ }^{22}$ U. Helmersson, S. Todorova, S. A. Barnett, J. E. Sundgren, L. C. Markert, and J. E. Greene, J. Appl. Phys. 62(2), 481 (1987).

${ }^{23}$ J. K. Park, H. J. Park, J. H. Ahn, and Y. J. Baik, Surf. Coat. Technol. 203(20-21), 3099 (2009).

${ }^{24}$ I. W. Kim, Q. Li, L. D. Marks, and S. A. Barnett, Appl. Phys. Lett. 78(7), 892 (2001).

${ }^{25}$ Q. Li, I. W. Kim, S. A. Barnett, and L. D. Marks, J. Mater. Res. 17(5), 1224 (2002)

${ }^{26}$ J. Lin, N. Zhang, Z. Wu, W. D. Sproul, M. Kaufman, M. Lei, and J. J. Moore, Surf. Coat. Technol. 228, S601-S606 (2013).

${ }^{27}$ M. Schlögl, C. Kirchlechner, J. Paulitsch, J. Keckes, and P. H. Mayrhofer, Scr. Mater. 68(12), 917-920 (2013).

${ }^{28}$ W. C. Oliver and G. M. Pharr, J. Mater. Res. 7(6), 1564 (1992).

${ }^{29}$ B. Alling, A. V. Ruban, A. Karimi, O. E. Peil, S. I. Simak, L. Hultman, and I. A. Abrikosov, Phys. Rev. B 75(4), 045123 (2007).

${ }^{30}$ A. O. Eriksson, J. Q. Zhu, N. Ghafoor, M. P. Johansson, J. Sjölén, J. Jensen, M. Odén, L. Hultman, and J. Rosén, Surf. Coat. Technol. 205(15), 3923-3930 (2011).

${ }^{31}$ A. Knutsson, I. C. Schramm, K. Asp Grönhagen, F. Mücklich, and M. Odén, J. Appl. Phys. 113(11), 114305 (2013).

${ }^{32}$ I. Povstugar, P. Choi, D. Tytko, J. Ahn, and D. Raabe, Acta Mater. 61, 7534-7542 (2013)

${ }^{33}$ B. Zhou and A. C. Powell, J. Membr. Sci. 268(2), 150-164 (2006).

${ }^{34}$ S. M. Wise, J. S. Kim, and W. C. Johnson, Thin Solid Films 473(1), 151 (2005).

${ }^{35}$ R. C. Ball and R. L. H. Essery, J. Phys. Condens. Matter 2(51), 10303-10320 (1990).

${ }^{36}$ P. H. Mayrhofer, D. Music, and J. M. Schneider, J. Appl. Phys. 100(9), 094906 (2006).

${ }^{37}$ F. Tasnádi, I. A. Abrikosov, L. Rogström, J. Almer, M. P. Johansson, and M. Odén, Appl. Phys. Lett. 97(23), 231902 (2010).

${ }^{38}$ M. P. Johansson Jöesaar, N. Norrby, J. Ullbrand, R. M'Saoubi, and M. Odén, Surf. Coat. Technol. 235, 181-185 (2013).

${ }^{39}$ D. Holec, L. Zhou, R. Rachbauer, and P. H. Mayrhofer, J. Appl. Phys. 113(4), 113510 (2013).

${ }^{40}$ H. Oettel, R. Wiedemann, and S. Preißler, Surf. Coat. Technol. 74-75(1), 273 (1995).

${ }^{41}$ A. Hörling, L. Hultman, M. Odén, J. Sjölén, and L. Karlsson, J. Vac. Sci. Technol. A 20(5), 1815 (2002). 
${ }^{42}$ B. Alling, M. Odén, L. Hultman, and I. A. Abrikosov, Appl. Phys. Lett. 95(18), 181906 (2009).

${ }^{43}$ N. Norrby, M. P. Johansson, R. M'Saoubi, and M. Odén, Surf. Coat. Technol. 209, 203-207 (2012).

${ }^{44}$ D. Holec, F. Rovere, P. H. Mayrhofer, and P. B. Barna, Scr. Mater. 62(6), 349 (2010).
${ }^{45}$ N. Norrby, H. Lind, G. Parakhonskiy, M. P. Johansson, F. Tasnádi, L. S. Dubrovinsky, N. Dubrovinskaia, I. A. Abrikosov, and M. Odén, J. Appl. Phys. 113(5), 053515 (2013).

${ }^{46}$ H. Willmann, P. H. Mayrhofer, L. Hultman, and C. Mitterer, J. Mater. Res. 23(11), 2880-2885 (2008).

${ }^{47}$ J. W. Cahn, Acta Mater. 9(9), 795-801 (1961). 